\title{
A Rights-Based Approach to Board Quotas and How Hard Sanctions Work for Gender Equality
}

Dr Anne Laure Humbert, Centre for Diversity Policy Research and Practice, Oxford Brookes University

Professor Elisabeth K. Kelan, Essex Business School, University of Essex

Dr Kate Clayton-Hathway, Centre for Diversity Policy Research and Practice, Oxford Brookes University

Pre-print as accepted by the European Journal of Women's Studies

\section{Introduction}

Women's under-representation in decision-making has been a strong focus of EU policy since the mid-1990s when the topic was inscribed in the Beijing Platform for Action and incorporated in key strategic documents such as the Strategy for Equality between Women and Men 2010-2015 (European Commission, 2010b) and the Strategic Engagement for Gender Equality 2016-2019 (European Commission, 2015). Inequalities are most marked among corporate board representation (De Bonfils et al., 2013; Humbert et al., 2015). To remedy this, and following the introduction of board quotas in Norway in 2003, EU-level legislation was suggested by Commissioner Reding in 2011 and in 2017 by Commissioner Jourová. However, board quotas continue to be a contested and highly divisive topic. 
The legitimacy of using quotas in politics (Krook, 2006; Dahlerup, 2008; Meier, 2008) or in publicly listed companies (Tienari et al., 2009; Teigen, 2012; Seierstad, 2013; Terjesen and Sealy, 2016), rather than waiting for parity, has often been debated. Here, we explore the relationship between board quotas, how gender equal a country is and women's board representation in the EEA in the period 2006 to 2018. Gender equality is understood as the gap between women and men in various societal aspects such as work, education or health. Furthermore, we differentiate between different types of sanctions and measures to understand potential relationships with women's board representation. The rationale for this work is to bridge the gap between quotas as a remedy to women's under-representation on boards and structural inequalities or masculine domination (Lombardo and Meier, 2006; Gabaldon et al., 2016). The relationship between levels of gender equality and quotas on women's board representation has seldom been examined (for an exception see Iannotta et al., 2016), and sanctions have been neglected. Board quotas are often justified by the 'business case' - for instance in relation to financial performance, business strategy, reputation or social/ethical aspects (Kirsch, 2018). This is in line with a wider move away from rights-based approaches (Elomäki, 2015) which aim at a transformation of legal, social and economic structures that enable individuals to exercise and enjoy their rights equally outside of power relations, notably those operating along the axis of gender (Carella and Ackerly, 2017). We argue that a greater focus on a rights-based approach would be beneficial for the discourses on gender on boards.

Examining board equality across various contexts remains rare (for an exception see Bullough et al., 2012). We therefore seek to respond to calls to develop multi-level theories (Hitt et al., 2007) and analyze the relationship between business and society (Jones, 1983), following on from the approach of Terjesen et al. (2015) who examined the influence of different institutional domains on gender board quota legislation and women's board representation. This responds to calls for conducting comparative research across countries (Terjesen and Singh, 2008; Grosvold and Brammer, 2011; Terjesen et al., 2015) and particularly the influence of cultural norms in society (Iannotta et al., 2016). The article 
thus contributes to the literature by examining the relation between women's underrepresentation on boards and societal or institutional factors such as the presence of board quotas, sanctions and gender equality. Methodologically, this is achieved by conducting a comparative analysis across EEA countries but also over time in response to calls for longitudinal research that examines the effects of regulatory mechanisms (Klettner et al., 2016).

The paper first summarizes key developments in relation to gender equality in decisionmaking and board quotas in the EU. It then formulates hypotheses about how gender equality and legislated quotas affect women's representation on boards. The results show that - as can be expected - board quotas work, but that the context in which they are introduced matters. Furthermore, results show that sanctions attached to board quotas also matter. Women's board representation is highest where there are both board quotas with hard sanctions and higher gender equality in society.

\section{The divisive topic of board quotas}

Women's low representation on boards is the result of multiple barriers and is recognized as an important challenge (European Commission, 2012a) and a central feature of EU policy (European Commission, 2010a; European Commission, 2015). The issue of women's underrepresentation on corporate boards is presented as one related to the 'business case' rather than about fairness and equality, exemplified in a speech given by former Commissioner Viviane Reding in 2011 (Reding, 2011).

On $1^{\text {st }}$ March 2011, Commissioner Reding launched the 'Women on Board Pledge for Europe' (European Commission, 2011), calling publicly listed companies in the EU to sign a voluntary commitment to reach a level of representation of women of $30 \%$ by 2015 , increasing to $40 \%$ by 2020 . The Pledge received initial widespread support from other EU institutions, including the European Parliament (European Parliament, 2011; European 
Parliament, 2012), but with mixed support at national level (European Commission, 2012a).

In light of the lack of progress, the European Commission drafted a proposal for quota legislation (European Commission, 2012b). The proposal only concerned publicly listed companies, and not small and medium enterprises. It was also devised as a temporary measure, with an expiration date set in 2028. In 2013, the European Parliament backed the proposal, however in 2014, ministers did not agree on how gender-balanced boards would be best achieved (Council of the European Union, 2014a). A new draft Directive was produced by the European Commission, watering down the initial version by no longer providing for mandatory quotas, but instead on fairer selection mechanisms. In 2014, ministers discussed the draft Directive but were unable to reach an agreement (Council of the European Union, 2014b) and the issue was not discussed in further Council meetings. It therefore seems that despite the efforts put by various institutional actors in devising an EU Directive on board quotas, this attempt has been unsuccessful. By end of 2017, the European Commissioner in charge of justice and gender equality announced a renewed push for gender quotas (Boffey, 2017), but with little progress at the time of writing. However, the impact of these efforts at national level cannot be underestimated since several European countries have adopted board quotas and debates about whether to implement them in other countries continue to take place. This article contributes empirically to these debates by analyzing the extent to which progress in women's board representation stems from greater gender equality and/or the implementation of board quotas.

\section{Gender Equality, Board Quotas and Women's Representation in Decision-making}

The underrepresentation of women in decision-making has been related to differences in aspirations (Lips, 2001) that explain that women 'lack ambition' or 'choose' not to put themselves forward. This view relies on an agentic vision of women in relation to their path towards decision-making that ignores how national culture can contribute to women's 
'choices' (Grosvold and Brammer, 2011). The gender paradigm operates at individual level, with its collective aggregation serving to shape how gender equal a society is. It is therefore imperative to examine, in a cross-national setting, what the relationship is between gender equality in society and representation level. As Werhane and PainterMorland (2011: 2) state, there is a need to "fundamentally re-evaluate our stereotypical understandings of leadership: the places where it occurs, the structures it requires and the individuals who participate in it". Walby (2009) theorises gender equality in relation to complex inequalities. This describes three approaches that gender equality can take, and has informed both policy and academic discussions. First, the sameness approach, which largely relies on using (hegemonic) men as the benchmark for women's achievements. Second, the difference approach, where the different contributions that women and men can make are recognised and valued equally. Third, the transformative approach in which the focus is on changing the systems through restructuring groups and standards. The introduction of legislated quotas can respond to all three approaches. It can aim at redressing women's under-representation on boards in numerical terms towards parity. However, women's numerical representation does not mean they achieve substantive representation (Celis et al., 2008), with the latter more aligned with transformative approaches. We argue that both the sameness and difference approaches are largely aligned with arguments rooted in rights-based approaches (Chant and Sweetman, 2012), where ensuring women's representation is seen as the right thing to do based on a social justice argument. We contrast this with the business case argument, which we see as more aligned to the difference approach. This is because the predominant argument therein is that women and men bring different skills and talents that in turn may be beneficial to organisations. Informed by rights-based approaches, we argue that women's under-representation in decision-making can be explained by the cumulative effect of inequalities and discrimination that operate at all levels and particularly societal context.

Gender inequalities across countries persist, and may undermine women's access to decision-making positions by failing to counteract the stereotypes that have held women 
back (Peters et al., 2013). Countries that are more gender equal may also provide women with greater human capital (Wright et al., 1995) or alternatively lead to greater legitimacy and greater opportunities to leverage experience (Post and Byron, 2015). However, any progress might be hindered by a lack of affordable childcare or a supportive taxation regime (Klettner et al., 2016). We therefore hypothesize that the gender equality context of a given country is positively related to the extent to which women are represented in top leadership positions:

Hypothesis 1: Women's representation on corporate boards of directors is higher in countries that are more gender equal.

The 'business case' approach argues that the low proportion of women on boards is not only an injustice in itself, but can also have potentially harmful effects on organizations. Studies have argued that greater gender balance on boards leads to better business performance and overall outcomes (Bilimoria, 2006; Terjesen et al., 2009; European Commission, 2012a). However, that might be contingent on whether a voluntary or regulatory approach was adopted (Labelle et al., 2015). To tackle the underrepresentation of women in decision-making positions, the policy context has been infused by passionate discourses on whether or not to use board quotas, as well as their (un)intended consequences (Terjesen et al., 2015). While it is clear that quota legislation generates change greater than any other interventions (Terjesen et al., 2015), evidence from Norway suggests that quotas have not been successful at raising women's board representation on boards much beyond the 40\% mark (Seierstad and Opsahl, 2011; Wang and Kelan, 2013). We therefore propose the following hypothesis:

Hypothesis 2: Countries in which board quotas have been introduced have a higher representation of women on boards.

In politics, the introduction of quotas largely responds to the need for 'critical acts' to be performed (Dahlerup, 1988) that may speed up the process of 'incremental track' and create a 'fast track' (Dahlerup and Freidenvall, 2005). Krook (2006) also shows that support for 
political quotas is related to whether they are consistent with existing or emerging societal notions of equality and representation but also whether they are supported by international norms and spread through transnational sharing. Like political quotas, board quotas are the product of the context in which they are instituted, with Terjesen et al. (2015) arguing that three core factors are at play: family welfare provision to support women's participation in the labor market; left leaning governments; and a legacy of gender equality initiatives in the country. The extent to which the introduction of legislated board quotas can then modulate the strength of the hypothesized relationships between levels of gender equality and women's board representation becomes pertinent. To examine these dynamics, the relationship between having both legislated board quotas and greater gender equality with women's board representation is considered:

Hypothesis 3: The presence of legislated board quotas moderates the positive relationship between levels of gender equality and women's board representation $(\mathrm{H1})$.

\section{Methodology}

The analysis relies on a panel dataset (2006-2018), for all EEA countries except Lichtenstein (28 EU Member States plus Iceland and Norway). This period corresponds to a period of great debates in both the academic and policy arenas, following the introduction of a 40\% quota for women directors in Norway in 2003 (Terjesen et al., 2015).

\section{Variables}

The dependent variable is the proportion of women on the boards of public quoted companies. These data have been collected since 2003 (European Institute for Gender Equality, 2018) and cover the gender balance in key positions at national level in the largest publicly listed companies (defined as the members, up to a maximum of 50 , of the primary blue-chip index e.g. FTSE 100 or DAX30). The highest decision-making body can include either a supervisory board or a board of directors depending on the company system. Data 
are compiled from a variety of sources, including company websites, stock-exchange websites and the companies' annual reports (Table 1).

\author{
Insert Table 1 about here
}

We use the World Economic Forum's Global Gender Gap Index (World Economic Forum, 2018) to measure how gender equal a country is (Table 2). It consists of a single score that ranges from 0 to 1 (rescaled between 0 and 100 for easier interpretation). It has been used in other gender-related corporate governance research (e.g. Post and Byron, 2015). The concurrent validity (Kerlinger and Howard, 1964) of the Global Gender Gap Index can be ascertained by noticing that there is a strong correlation with other composite measures of gender equality such as the Gender Equality Index ( $r=0.82)$ (Humbert et al., 2015).

\title{
Insert Table 2 about here
}

A variable that captures the board quotas is included, with information collected and triangulated from a variety of sources. By 2018, eight EEA countries had legislated quotas for publicly listed companies (Table 3).

\footnotetext{
Insert Table 3 about here
}

\section{Modelling}

Panel data regressions with fixed effects were used to assess the relationship between levels of gender equality and women's representation on boards, and explore whether this is moderated by the presence of legislated board quotas: 


$$
\mathrm{WOB}_{i t}=\beta_{1}+\sum_{t=2}^{12} \beta_{t} d_{t}+\gamma_{1} \mathrm{GE}_{i t}+\propto_{1} \mathrm{LQ}_{i t}+\varepsilon_{i t}
$$

where $\mathrm{d}$ is a dummy variable, WOB stands for 'women's representation on boards', GE for 'levels of gender equality', and LQ for the presence of a 'legislated board quota' where one has been introduced ( 0 where there is no quota, alternatively 1$)$, in country $\mathrm{i}$ and time $\mathrm{t}$ (ranging from 1 to 12). We focus on the date at which the board quotas were introduced, rather than the date full implementation is expected, as effects are likely to start when they are first announced (Singh et al., 2015). Scores for the Gender Gap Index are mean-centred to minimize potential issues with multicollinearity (Aiken and West, 1991). The panel data allows us, through the inclusion of fixed effects, to control for the potential idiosyncratic effects of time. This is done through the inclusion of a dummy variable in the model for each year (to avoid multi-collinearity, dummies are excluded for the year 2006). GDP per capita is included as a control variable to account for the economic development level of each country.

\section{Post-hoc analysis}

To provide a more nuanced account of the potential effects of different types of measures on women's board representation, further analyses were conducted which incorporate three types: a legislated board quota with hard sanctions such as either or both fines and the suspension/dismissal of directors (e.g. Norway); a legislated board quota with soft sanctions such as a 'complain or explain' mechanism (e.g. Germany) or the ineligibility to receive public funds (e.g. Spain); another type of measure such as a Code of Corporate Governance. Where a Code of Governance was followed by quota legislation, only the latter is considered. The analysis also explored potential interactions, following the logic of the argument in the main analysis. 


\section{Correlation matrix}

All three groups of variables are strongly correlated to each other over time (Table 4). As all correlations are moderate (less than 0.8), there is no evidence of a problem with multicollinearity. Potential multi-collinearity was further assessed through Variance Influence Factors (VIFs), with all values well below 10 (Neter et al., 1989).

Insert Table 4 about here

\section{Results}

Model 1 (Table 5) suggests that higher gender equality scores are positively associated with women's representation on boards $(\beta=1.40, \mathrm{p}<0.01)$, supporting Hypothesis 1 . Model 2 confirms that women's board representation is higher in countries where legislated board quotas are in place, supporting Hypothesis $2(\beta=11.99, \mathrm{p}<0.01)$. Model 3 confirms that both gender equality and boards quotas are associated with higher representation of women on boards $(\beta=1.22$ and $\beta=7.61$ respectively, $\mathrm{p}<0.01)$.

\section{Insert Table 5 about here}

Model 4 introduces an interaction parameter between the presence of legislated board quotas and gender equality. This provides a positive coefficient $(\beta=0.35, \mathrm{p}<0.05)$ which supports Hypothesis 3 and suggests that having legislated board quotas combined with higher levels of gender equality is associated with higher levels of women's board representation.

In 2018, the scores of the Global Gender Gap Index ranged from 67 (Hungary) to 86 out of 100 (Iceland). With this in mind, Model 4 shows that there is about an additional one 
percentage point increase (1.13) in representation for every point increase in the score of the Global Gender Gap Index - all other variables staying constant. As for the interaction parameter, it shows that the effects of having legislated board quotas is only marginally higher than not having them for countries at the lower end of the Global Gender Gap Index. This contrasts with countries higher gender equality, as can be seen by the steeper slope for countries with legislated board quotas, illustrated in Figure 1.

Insert Figure 1 about here

As part of the post-hoc analysis, measures were expanded to include both board quotas with soft/hard sanctions and other measures such as codes of governance (Table 6). Model 5 shows that the positive effect of board quotas on women's board representation is higher when associated with hard sanctions such as fines and/or the suspension or dismissal of directors $(\beta=18.94, \mathrm{p}<0.01)$ than soft sanctions $(\beta=7.20, \mathrm{p}<0.01)$. Adding information in Model 6 about the presence of Codes of Governance shows that they too have a positive effect on women's board representation $(\beta=8.97, p<0.01)$, but less than board quotas with hard sanctions $(\beta=23.03, p<0.01)$ or soft sanctions $(\beta=10.36, p<0.01)$. Adding gender equality levels in Model 7 reduces the effects of the presence of legislated board quotas with hard sanctions $(\beta=14.14, \mathrm{p}<0.01)$ or soft sanctions $(\beta=6.98, \mathrm{p}<0.01)$ and codes of governance $(\beta=4.27, \mathrm{p}<0.01)$.

\section{Insert Table 6 about here}

Models 8 and 9 show that both board quotas hard sanctions and codes interact with level of gender equality, but not board quotas with soft sanctions. Having a code of governance and lower gender equality is associated with a representation of women on boards similar to 
countries with no measures in place. However, a code of governance where there are higher levels of gender equality is associated with a level of women's representation on boards just below that of countries with board quotas with hard sanctions (Figure 2).

Insert Figure 2 about here

\section{Beyond the 'quota question': a call for focusing on rights}

The analysis shows where there is more gender equality at societal level coupled with board quotas (particularly with hard sanctions), there are more women represented on corporate boards. This adds to previous research by showing that board quotas work best in countries that are more gender equal. Furthermore, quotas work more or less efficiently depending on sanctions. Board quotas with hard sanctions work best, regardless of the level of gender equality in a country. Having a code of governance, when associated with higher levels of gender equality, is also associated with higher levels of women's board representation. However, board quotas with soft sanctions are associated with results that are only marginally better than not having any measure in place.

Overall, this provides evidence that a targeted action such as legislated board quotas can be a key driver of progress, particularly when associated with hard sanctions. If hard sanctions exist, actors are more likely to comply with and act upon the board quota because there is a real risk to the corporation that needs to be mitigated. With soft sanctions, risks might not appear as particularly high, leading to non-action. If board quotas are successful in pushing for change, a counter-movement might try to undo that (Roggeband, 2018). Board quotas can cause resistance and negativity within organizations because they are perceived as displacing 'merit' (Humbert et al., 2018). However, that is much more difficult if hard sanctions are in place because there are punitive consequences for non-compliance that could hurt a corporation. A strategy to mitigate risk is to comply rather than to fight the 
quota. That does not mean that resistance does not exist, because it is exactly the ability of board quotas with hard sanctions to produce change that creates deep-seated resistance and opposition (Ahrens, 2018).

In addition, our results suggest that board quotas cannot be relied upon as instruments of progress independently of a contextual environment that is more gender equal. Board quotas largely speak to a business or market logic where gender equality is largely understood through the prism of 'sameness' or 'difference' rather than transformation (Walby, 2009), although this takes different forms in different societal contexts (Tienari et al., 2009). This makes it even more pressing to consider the gender equality context in which board quotas are proposed or implemented, since greater gender equality potentially mitigates these risks by allowing greater space for questioning and criticizing how to tackle women's under-representation on boards. This is particularly the case where gender equality is understood as a political and transformative project that seeks to transform power relations and address inequalities of minoritized groups, including women (Chant and Sweetman, 2012). In light of the growing trend for EU institutions and related actors to follow a market-oriented discourse (Elomäki, 2015), which is also dominant in studies on gender on boards (cf. Kirsch, 2018), these results provide empirical evidence of the importance of not foregoing a rights-based approach in calling for greater equality in decision-making. Such an approach would mean moving away from focusing on efficiency and productivity gains and instead centre on women's rights to participate and contribute to decision-making on boards. Women's representation on boards ought to be more than simply a numbers' game. Quotas, as Jansson (2017: 10) argues, shape women into "tokens of equality rather than as agents for liberation". What is at stake is the substantive equal representation of women and men as leaders that privilege equality ideals over the market forces inherent in the business case approach (Tienari et al., 2009). As outlined by Elomäki (2015), women's under-representation in leadership positions has become less about a focus on substantive representation and more a rational economic exercise in fully using women's human capital. To transform gender relations, our results suggest that this is a 
false dichotomy in that the combination works best at least in relation to numerical representation. It is likely that these relationships are more complex than the ones considered here, and that there is in fact a virtuous circle at play whereby greater representation contributes to greater equality and/or the adoption of legislated measures, ultimately feeding back into greater representation. Although board quotas are successful in remedying women's board under-representation, prior research has shown that a focus on appointing more women onto boards often leads to a form of elite reproduction where women appointed to boards come from a similar background to men appointed to boards (Brown and Kelan, in preparation). Elite women might benefit particularly and are likely to be beneficiaries of this reproduction system, which extends beyond ethnicity or class alone.

The article has contributed to the understanding of how gender equal representation on boards is related to gender equality and quotas. It extends the literature on gender and decision-making by examining whether the representation of women on boards in EEA countries relates to either or both levels of gender equality and legislated board quotas. The research itself is rooted in current academic and policy debates on the introduction of board quotas, and demonstrates the importance of ensuring a baseline context of equality. Through this analysis, the article has extended the research beyond seeing gender and decision-making on an individual level, instead examining the topic within its societal context. In particular, the paper makes two contributions through looking at both relationships with women's board representation simultaneously and adding a longitudinal perspective across different countries. Panel data analysis represents a trade-off between being able to rely on rich data on the one hand (owing to the richness of data availability in the EEA), and the ability to generalize on the other when it comes to a broader geographical context. The findings may not be applicable to some countries, particularly where their societal context varies greatly from the socio-demographic levels afforded to EEA countries. In addition, the European context is specific in that the threat of board quotas - at EU or national level - combined with isomorphic effects have increased efforts to promote women's board representation (Terjesen et al., 2015). Nevertheless, the 
relationships examined in this analysis have wider relevance and implications beyond the region (Norris and Inglehart, 2001).

In relation to further research, thus far, legislated board quotas - particularly those underpinned by hard sanctions - have hardly been implemented. By 2018, only eight EEA countries had introduced legislated boards quotas, ranging from as early as 2007 to 2015 . Furthermore, it is likely that there is a lag-time effect. As full implementation remains recent, the complete effect of legislated board quotas is yet to be felt. Repeating such studies in the future, as the number of countries with legislated board quotas increases, and as implementation enters into force is needed. Models taking lagged-variables into consideration might provide additional insights. The relatively short time-series available for this article, combined with the recent introduction of legislated board quotas, does not yet permit this type of analysis. The extent to which this then leads to a cultural change on the board itself, and lower down in the organization then remains a question of interest, particularly as the proportion of women as corporate leaders continues to grow. Such research could, for instance, explore whether more women on boards means that there is a greater focus on gender equality within organizations. This clearly indicates that further research should explore the links between micro, meso and macro perspectives in relation to gender and leadership. Where feasible, this should consider the possible actors involved, particularly the role they play at the intersection of these different levels and their contribution to pushing for change in respective countries (Seierstad et al., 2017). Finally, no distinction is made between non-executive and executive functions as data in the original source are only available for 2012 and onwards. Following previous research in this specific direction (Post and Byron, 2015) further work should consider extending the analysis in this area.

Overall, this article provides evidence that a higher representation of women on company boards is the reflection of societies that are more gender equal and/or have introduced legislated board quotas. Furthermore, the types of measures and their sanctions matter, with 
board quotas combined with hard sanctions appearing most effective. We conclude that for further and faster progress to be made, the introduction of legislated board quotas shows great potential, but only in combination with striving for a gender equal society and using hard sanctions. Unsurprisingly, board quotas work to increase the representation of women on boards, but they work best in contexts that are more gender equal and where quotas come with hard sanctions. Our results call for not losing the focus on 'rights' at the expense of the more palatable 'business case' for board quotas when striving for equality on corporate boards. 


\section{References}

Ahrens P (2018) Indirect opposition: Diffuse barriers to gender+ equality in the European Union. In: Verloo M (ed) Varieties of Opposition to Gender Equality in Europe. New York: Routledge, pp.77-97.

Aiken LS and West SG (1991) Multiple Regression: Testing and Interpreting Interactions, Newbury Park, CA: Sage.

Bilimoria D (2006) The relationship between women corporate directors and women corporate officers. Journal of Managerial Issues 18: 47-61.

Boffey D (2017) EU to push for 40\% quota for women on company boards. The Guardian, 20 November.

Brown SE and Kelan EK (in preparation) Gender and Corporate Boards - The Appointment Process, New York: Routledge.

Bullough A, Kroeck KG, Newburry W, Kundu SK and Lowe KB (2012) Women's political leadership participation around the world: An institutional analysis. The Leadership Quarterly 23: 398-411.

Celis K, Childs S, Kantola J and Krook ML (2008) Rethinking women's substantive representation. Representation 44: 99-110.

CESifo (2013) Gender Quotas on Boardroom Representation in Europe. Available at: https://www.cesifo-group.de/de/ifoHome/facts/DICE/Labour-Market/Labour-

Market/Anti-discrimination-Gender/gender-quota-boardroomrepresentation_report/fileBinary/gender-quotas-boardroom-representation_dicereport313db3.pdf. (accessed 8/11/2018).

Chant S and Sweetman C (2012) Fixing women or fixing the world? 'Smart economics', efficiency approaches, and gender equality in development. Gender \& Development 20: 517-529.

Council of the European Union (2014a) 3323rd Council meeting of the Employment, Social Policy, Health and Consumer Affairs. Available at: https://data.consilium.europa.eu/doc/document/ST-11122-2014-INIT/en/pdf. （accessed 28 November 2018).

Council of the European Union (2014b) 3357th Council meeting Employment, Social Policy, Health and Consumer Affairs. Available at: https://data.consilium.europa.eu/doc/document/ST-16803-2014-REV-1/en/pdf. (accessed 28 November 2018).

Dahlerup D (1988) From a small to a large minority: Women in scandinavian politics. Scandinavian Political Studies 11: 275-298.

Dahlerup D (2008) Gender quotas - Controversial but trendy. International Feminist Journal of Politics 10: 322-328.

Dahlerup D and Freidenvall L (2005) Quotas as a 'fast track' to equal representation for women. International Feminist Journal of Politics 7: 26-48.

de Bonfils L, Humbert AL, Ivaškaitè-Tamošiūnè V, Manca AR, Nobrega L, Reingardè J and Lestón IR (2013) Gender Equality Index Report. European Institute for Gender Equality. Available at: http://eige.europa.eu/content/document/gender-equality-index-report. (accessed 28 November 2018). 
Elomäki A (2015) The economic case for gender equality in the European Union: Selling gender equality to decision-makers and neoliberalism to women's organizations. European Journal of Women's Studies 22: 288-302.

European Commission (2010a) Communication from the Commission: Europe 2020, A strategy for smart, sustainable and inclusive growth. Available at: http://ec.europa.eu/eu2020/pdf/COMPLET\%20EN\%20BARROSO\%20\%20\%20007\%20 -\%20Europe\%202020\%20-\%20EN\%20version.pdf. (accessed 28 November 2018).

European Commission (2010b) Strategy for Equality between Women and Men 2010-2015. Available at: http://ec.europa.eu/social/BlobServlet?docId=6568\&langId=en. (accessed 9 October 2018).

European Commission (2011) EU Justice Commissioner Viviane Reding meets European business leaders to push for more women in boardrooms. Available at: http://europa.eu/rapid/press-release_IP-11-242_en.htm?locale=en. $\quad$ (accessed 28 November 2018).

European Commission (2012a) Women in Economic Decision-making in the EU: Progress Report. Available at: https://publications.europa.eu/en/publication-detail//publication/8832ea16-e2e6-4095-b1eb-cc72a22e28df/language-en. (accessed 28 November 2018).

European Commission (2012b) Women on Boards: Commission proposes $40 \%$ objective. Available at: http://europa.eu/rapid/press-release_IP-12-1205_en.htm. (accessed 28 November 2018).

European Commission (2015) Strategic Engagement for Gender Equality 2016-2019. Available at: https://ec.europa.eu/anti-trafficking/eu-policy/strategic-engagement-gender-equality2016-2019_en. (accessed 9 October 2018).

European Commission (2016) Gender balance on corporate boards - Europe is cracking the glass ceiling. Available at: http://ec.europa.eu/newsroom/document.cfm?doc_id=46280. (accessed 8 November 2018).

European Institute for Gender Equality (2018) Database on Women and Men in Decisionmaking. Available at: https://eige.europa.eu/gender-statistics/dgs/browse/wmidm. (accessed 28 November 2018).

European Parliament (2011) Women and business leadership, European Parliament resolution of 6 July 2011 on women and business leadership. 2010/2115(INI).

European Parliament (2012) European Parliament resolution of 13 March 2012 on equality between women and men in the European Union. 2011/2244(INI).

Gabaldon P, Anca C, Mateos de Cabo R and Gimeno R (2016) Searching for women on boards: An analysis from the supply and demand perspective. Corporate Governance: An International Review 24: 371-385.

Grosvold J and Brammer S (2011) National institutional systems as antecedents of female board representation: An empirical study. Corporate Governance: An International Review 19: 116-135.

Hitt MA, Beamish PW, Jackson SE and Mathieu JE (2007) Building theoretical and empirical bridges across levels: Multilevel research in management. Academy of Management Journal 50: 1385-1399.

Humbert AL, Ivaškaitè-Tamošiūnė V, Oetke N and Paats M (2015) Gender Equality Index 2015 - Measuring gender equality in the European Union 2005-2012. European Institute for Gender Equality. Available at: 
http://eige.europa.eu/sites/default/files/documents/mh0215616enn.pdf. （accessed

November 2018).

Humbert AL, Kelan EK and van den Brink M (2018) The Perils of Gender Beliefs for Men Leaders as Change Agents for Gender Equality. European Management Review.

Iannotta M, Gatti M and Huse M (2016) Institutional complementarities and gender diversity on boards: A configurational approach. Corporate Governance: An International Review 24: 406-427.

Jansson M (2017) Gender equality in Swedish film policy: Radical interpretations and 'unruly' women. European Journal of Women's Studies.

Jones TM (1983) An integrating framework for research in business and society: A step toward the elusive paradigm? Academy of Management Review 8: 559-564.

Kerlinger FN and Howard BL (1964) Foundations of behavioral research: Educational and psychological inquiry.

Kirsch A (2017) Women's access to boards in Germany - Regulation and symbolic change. In: Seierstad C, Gabaldon P and Mensi-Klarbach H (eds) Gender Diversity in the Boardroom. Cham: Palgrave Macmillan.

Kirsch A (2018) The gender composition of corporate boards: A review and research agenda. The Leadership Quarterly 29: 346-364.

Klettner A, Clarke T and Boersma M (2016) Strategic and regulatory approaches to increasing women in leadership: Multilevel targets and mandatory quotas as levers for cultural change. Journal of Business Ethics 133: 395-419.

Krook ML (2006) Reforming representation: The diffusion of candidate gender quotas worldwide. Politics \& Gender 2: 303-327.

Labelle R, Francoeur C and Lakhal F (2015) To regulate or not to regulate? Early evidence on the means used around the world to promote gender diversity in the boardroom. Gender, Work \& Organization 22: 339-363.

Lips HM (2001) Envisioning positions of leadership: The expectations of university students in Virginia and Puerto Rico. Journal of Social Issues 57: 799-813.

Lombardo E and Meier P (2006) Gender mainstreaming in the EU: Incorporating a feminist reading? European Journal of Women's Studies 13: 151-166.

Meier P (2008) A gender gap not closed by quotas. International Feminist Journal of Politics 10: 329-347.

Neter J, Wasserman W and Kutner MH (1989) Applied Linear Regression Models, Homewood, IL: Irwin.

Norris P and Inglehart R (2001) Cultural obstacles to equal representation. Journal of Democracy 12: $126-140$.

Peters K, Ryan M, Haslam SA and Morgenroth T (2013) The Psychology and Economics of Women in Leadership. European Parliament. Available at: http://www.europarl.europa.eu/document/activities/cont/201303/20130315ATT63291/20 130315ATT63291EN.pdf. (accessed 28 November 2018).

Post C and Byron K (2015) Women on boards and firm financial performance: A meta-analysis. Academy of Management Journal 58: 1546-1571.

Reding V (2011) More Women in Europe's Boardrooms - The Business Case. Available at: http://europa.eu/rapid/press-release_IP-11-242_en.htm. (accessed 28 November 2018).

Roggeband C (2018) The good, the bad, and the ugly: Making sense of opposition to feminisms from a social-movement perspective. In: Verloo M (ed) Varieties of Opposition to Gender Equality in Europe. New York: Routledge, pp.19-37. 
Seierstad C (2013) Gender quotas on corporate boards in Norway, necessary but not ideal. In: Machold S, Huse M, Hansen K and Brogi M (eds) Getting Women on to Corporate Boards: A Snowball Starting in Norway. Cheltenham UK: Edward Elgar Publishing, 138146.

Seierstad C and Opsahl T (2011) For the few not the many? The effects of affirmative action on presence, prominence, and social capital of women directors in Norway. Scandinavian Journal of Management 27: 44-54.

Seierstad C, Warner-Søderholm G, Torchia M and Huse M (2017) Increasing the number of women on boards: The role of actors and processes. Journal of Business Ethics 141: 289315.

Singh V, Point S and Moulin Y (2015) French supervisory board gender composition and quota threat: changes from 2008 to 2010. Gender in Management: An International Journal 30: 551-571.

Teigen M (2012) Gender quotas on corporate boards: On the diffusion of a distinct national policy reform. In: Engelstad F and Teigen M (eds) Firms, Boards and Gender Quotas: Comparative Perspectives. Emerald Group Publishing Limited, pp.115-146.

Terjesen S, Aguilera RV and Lorenz R (2015) Legislating a woman's seat on the board: Institutional factors driving gender quotas for boards of directors. Journal of Business Ethics 128: 233-251.

Terjesen S and Sealy R (2016) Board gender quotas: Exploring ethical tensions from a multitheoretical perspective. Business Ethics Quarterly 26: 23-65.

Terjesen S, Sealy R and Singh V (2009) Women directors on corporate boards: A review and research agenda. Corporate Governance: An International Review 17: 320-337.

Terjesen S and Singh V (2008) Female presence on corporate boards: A multi-country study of environmental context. Journal of Business Ethics 83: 55-63.

Tienari J, Holgersson C, Meriläinen S and Höök P (2009) Gender, management and market discourse: The case of gender quotas in the Swedish and Finnish media. Gender, Work \& Organization 16: 501-521.

Walby S (2009) Globalization and Inequalities: Complexity and Contested Modernities, London: Sage.

Wang M and Kelan E (2013) The gender quota and female leadership: Effects of the Norwegian gender quota on board chairs and CEOs. Journal of Business Ethics 117: 449-466.

Werhane PH and Painter-Morland M (2011) Leadership, gender, and organization. In: Werhane PH and Painter-Morland M (eds) Leadership, Gender, and Organization. London: Springer, pp.1-8.

World Economic Forum (2018) The Global Gender Gap Report 2018. Available at: https://www.weforum.org/reports/the-global-gender-gap-report-2018.

Wright EO, Baxter J and Birkelund GE (1995) The gender gap in workplace authority: A crossnational study. American Sociological Review 60: 407-435. 


\section{Tables}

Table 1: Percentage of women on the boards of the largest quoted companies by EU Member States, 2006-18

\begin{tabular}{|c|c|c|c|c|c|c|c|c|c|c|c|c|c|}
\hline & 2006 & 07 & 08 & 09 & 10 & 11 & 12 & 13 & 14 & 15 & 16 & 17 & 2018 \\
\hline Austria & 6 & 5 & 6 & 7 & 9 & 11 & 12 & 13 & 17 & 20 & 18 & 19 & 24 \\
\hline Belgium & 6 & 6 & 7 & 8 & 10 & 11 & 13 & 17 & 22 & 26 & 29 & 31 & 31 \\
\hline Bulgaria & 17 & 15 & 12 & 17 & 11 & 15 & 12 & 17 & 18 & 19 & 15 & 17 & 16 \\
\hline Croatia & - & 14 & 12 & 15 & 16 & 19 & 15 & 15 & 19 & 22 & 20 & 22 & 19 \\
\hline Cyprus & 6 & 2 & 3 & 3 & 4 & 5 & 8 & 7 & 9 & 9 & 11 & 10 & 11 \\
\hline Czech Republic & 8 & 11 & 13 & 13 & 12 & 16 & 16 & 11 & 4 & 10 & 10 & 15 & 16 \\
\hline Denmark & 12 & 15 & 17 & 18 & 18 & 16 & 21 & 23 & 24 & 26 & 27 & 30 & 31 \\
\hline Estonia & 13 & 10 & 8 & 6 & 7 & 7 & 8 & 7 & 7 & 8 & 9 & 7 & 7 \\
\hline Finland & 20 & 18 & 20 & 24 & 26 & 26 & 29 & 30 & 29 & 29 & 30 & 33 & 34 \\
\hline France & 8 & 9 & 9 & 10 & 12 & 22 & 25 & 30 & 32 & 36 & 41 & 43 & 44 \\
\hline Germany & 11 & 11 & 13 & 13 & 13 & 15 & 18 & 21 & 24 & 26 & 30 & 32 & 33 \\
\hline Greece & 8 & 11 & 6 & 5 & 6 & 6 & 8 & 8 & 9 & 10 & 9 & 11 & 10 \\
\hline Hungary & 12 & 11 & 16 & 13 & 14 & 5 & 7 & 11 & 12 & 18 & 12 & 15 & 15 \\
\hline Iceland & 6 & 10 & 10 & 16 & 16 & 21 & 36 & 48 & 45 & 44 & 45 & 43 & 46 \\
\hline Ireland & 5 & 6 & 7 & 8 & 8 & 9 & 9 & 11 & 11 & 15 & 17 & 18 & 18 \\
\hline Italy & 4 & 3 & 4 & 4 & 5 & 6 & 11 & 15 & 24 & 29 & 32 & 34 & 36 \\
\hline Latvia & 21 & 17 & 16 & 17 & 23 & 27 & 28 & 29 & 32 & 30 & 29 & 29 & 30 \\
\hline Lithuania & 16 & 18 & 16 & 15 & 13 & 14 & 18 & 16 & 17 & 14 & 14 & 14 & 14 \\
\hline Luxembourg & 1 & 3 & 3 & 3 & 4 & 6 & 10 & 11 & 12 & 12 & 13 & 12 & 14 \\
\hline Malta & 4 & 4 & 4 & 4 & 2 & 2 & 4 & 2 & 3 & 5 & 5 & 8 & 8 \\
\hline Netherlands & 8 & 14 & 14 & 15 & 15 & 18 & 22 & 25 & 25 & 26 & 28 & 30 & 30 \\
\hline Norway & 35 & 34 & 43 & 42 & 39 & 41 & 44 & 42 & 38 & 39 & 43 & 42 & 41 \\
\hline Poland & 9 & 12 & 10 & 10 & 12 & 12 & 12 & 12 & 15 & 19 & 19 & 20 & 20 \\
\hline Portugal & 7 & 3 & 3 & 4 & 5 & 6 & 7 & 9 & 9 & 14 & 14 & 16 & 17 \\
\hline Romania & 13 & 18 & 12 & 12 & 21 & 10 & 12 & 8 & 11 & 12 & 10 & 11 & 8 \\
\hline Slovakia & 10 & 24 & 18 & 18 & 22 & 15 & 14 & 24 & 18 & 13 & 13 & 15 & 21 \\
\hline Slovenia & 19 & 14 & 18 & 10 & 10 & 14 & 19 & 22 & 20 & 22 & 25 & 23 & 26 \\
\hline Spain & 4 & 6 & 8 & 10 & 10 & 11 & 12 & 15 & 17 & 19 & 20 & 22 & 23 \\
\hline Sweden & 24 & 24 & 27 & 27 & 26 & 25 & 26 & 26 & 28 & 33 & 37 & 36 & 36 \\
\hline United Kingdom & 12 & 12 & 12 & 12 & 13 & 16 & 19 & 21 & 24 & 28 & 27 & 27 & 29 \\
\hline
\end{tabular}

Source: European Institute for Gender Equality (2018) 
Table 2: Global Gender Gap Index scores in EEA countries, 2006-2018

\begin{tabular}{|c|c|c|c|c|c|c|c|c|c|c|c|c|c|}
\hline & 2006 & 07 & 08 & 09 & 10 & 11 & 12 & 13 & 14 & 15 & 16 & 17 & 2018 \\
\hline Austria & 0.70 & 0.71 & 0.72 & 0.70 & 0.71 & 0.72 & 0.74 & 0.74 & 0.73 & 0.73 & 0.72 & 0.71 & 0.72 \\
\hline Belgium & 0.71 & 0.72 & 0.72 & 0.72 & 0.75 & 0.75 & 0.77 & 0.77 & 0.78 & 0.75 & 0.75 & 0.74 & 0.74 \\
\hline Bulgaria & 0.69 & 0.71 & 0.71 & 0.71 & 0.70 & 0.70 & 0.70 & 0.71 & 0.74 & 0.72 & 0.73 & 0.76 & 0.76 \\
\hline Croatia & 0.71 & 0.72 & 0.70 & 0.69 & 0.69 & 0.70 & 0.71 & 0.71 & 0.71 & 0.71 & 0.70 & 0.71 & 0.71 \\
\hline Cyprus & 0.64 & 0.65 & 0.67 & 0.67 & 0.66 & 0.66 & 0.67 & 0.68 & 0.67 & 0.67 & 0.68 & 0.68 & 0.68 \\
\hline Czech Republic & 0.67 & 0.67 & 0.68 & 0.68 & 0.69 & 0.68 & 0.68 & 0.68 & 0.67 & 0.69 & 0.69 & 0.69 & 0.69 \\
\hline Denmark & 0.75 & 0.75 & 0.75 & 0.76 & 0.77 & 0.78 & 0.78 & 0.78 & 0.80 & 0.77 & 0.75 & 0.78 & 0.78 \\
\hline Estonia & 0.69 & 0.70 & 0.71 & 0.71 & 0.70 & 0.70 & 0.70 & 0.70 & 0.70 & 0.75 & 0.75 & 0.73 & 0.73 \\
\hline Finland & 0.80 & 0.80 & 0.82 & 0.83 & 0.83 & 0.84 & 0.85 & 0.84 & 0.85 & 0.85 & 0.85 & 0.82 & 0.82 \\
\hline France & 0.65 & 0.68 & 0.73 & 0.73 & 0.70 & 0.70 & 0.70 & 0.71 & 0.76 & 0.76 & 0.76 & 0.78 & 0.78 \\
\hline Ger & 0.75 & 0.76 & 0.74 & 0.74 & 0.75 & 0.76 & 0.76 & 0.76 & 0.78 & 0.78 & 0.77 & 0.78 & 0.78 \\
\hline & 0.65 & 0.66 & 0.67 & 0.67 & 0.69 & 0.69 & 0.67 & 0.68 & 0.68 & 0.69 & 0.68 & 0.69 & 0.70 \\
\hline & 0.67 & 0.67 & 0.69 & 0.69 & 0.67 & 0.66 & 0.67 & 0.67 & 0.68 & 0.67 & 0.67 & 0.67 & 0.67 \\
\hline Iceland & 0.78 & 0.78 & 0.80 & 0.83 & 0.85 & 0.85 & 0.86 & 0.87 & 0.86 & 0.88 & 0.87 & 0.88 & 0.86 \\
\hline Ireland & 0.73 & 0.75 & 0.75 & 0.76 & 0.78 & 0.78 & 0.78 & 0.78 & 0.79 & 0.81 & 0.80 & 0.79 & 0.80 \\
\hline Italy & 0.65 & 0.65 & 0.68 & 0.68 & 0.68 & 0.68 & 0.67 & 0.69 & 0.70 & 0.73 & 0.72 & 0.69 & 0.71 \\
\hline Latvia & 0.71 & 0.73 & 0.74 & 0.74 & 0.74 & 0.74 & 0.76 & 0.76 & 0.77 & 0.75 & 0.76 & 0.76 & 0.76 \\
\hline Lithuania & 0.71 & 0.72 & 0.72 & 0.72 & 0.71 & 0.71 & 0.72 & 0.73 & 0.72 & 0.74 & 0.74 & 0.74 & 0.75 \\
\hline Luxembourg & 0.67 & 0.68 & 0.68 & 0.69 & 0.72 & 0.72 & 0.74 & 0.74 & 0.73 & 0.74 & 0.73 & 0.71 & 0.71 \\
\hline Malta & 0.65 & 0.66 & 0.66 & 0.66 & 0.67 & 0.67 & 0.67 & 0.68 & 0.67 & 0.67 & 0.66 & 0.68 & 0.69 \\
\hline Netherla & 0.73 & 0.74 & 0.74 & 0.75 & 0.74 & 0.75 & 0.77 & 0.76 & 0.77 & 0.78 & 0.76 & 0.74 & 0.75 \\
\hline Norway & 0.80 & 0.81 & 0.82 & 0.82 & 0.84 & 0.84 & 0.84 & 0.84 & 0.84 & 0.85 & 0.84 & 0.83 & 0.84 \\
\hline Poland & 0.68 & 0.68 & 0.70 & 0.70 & 0.70 & 0.70 & 0.70 & 0.70 & 0.71 & 0.72 & 0.73 & 0.73 & 0.73 \\
\hline Portugal & 0.69 & 0.70 & 0.71 & 0.70 & 0.72 & 0.71 & 0.71 & 0.71 & 0.72 & 0.73 & 0.74 & 0.73 & 0.73 \\
\hline Romania & 0.68 & 0.69 & 0.68 & 0.68 & 0.68 & 0.68 & 0.69 & 0.69 & 0.69 & 0.69 & 0.69 & 0.71 & 0.71 \\
\hline Slovakia & 0.68 & 0.68 & 0.68 & 0.68 & 0.68 & 0.68 & 0.68 & 0.69 & 0.68 & 0.68 & 0.68 & 0.69 & 0.69 \\
\hline Slovenia & 0.67 & 0.68 & 0.69 & 0.70 & 0.70 & 0.70 & 0.71 & 0.72 & 0.74 & 0.78 & 0.79 & 0.81 & 0.78 \\
\hline Spain & 0.73 & 0.74 & 0.73 & 0.73 & 0.76 & 0.76 & 0.73 & 0.73 & 0.73 & 0.74 & 0.74 & 0.75 & 0.75 \\
\hline Sweden & 0.81 & 0.81 & 0.81 & 0.81 & 0.80 & 0.80 & 0.82 & 0.81 & 0.82 & 0.82 & 0.82 & 0.82 & 0.82 \\
\hline United Kingdom & 0.74 & 0.74 & 0.74 & 0.74 & 0.75 & 0.75 & 0.74 & 0.74 & 0.74 & 0.76 & 0.75 & 0.77 & 0.77 \\
\hline
\end{tabular}

Source: World Economic Forum (2006-2018) 
Table 3: Quotas and Codes of Corporate Governance across the European Union Member States

\begin{tabular}{|c|c|c|c|}
\hline Country & $\begin{array}{l}\text { Legislated quotas for } \\
\text { Listed Companies }\end{array}$ & Sanctions & $\begin{array}{l}\text { Code of Corporate Governance or other national } \\
\text { measure }\end{array}$ \\
\hline Austria & & & $\begin{array}{l}\text { 2009: Corporate Code of Governance recommends the } \\
\text { representation of both women and men in supervisory } \\
\text { boards. }\end{array}$ \\
\hline Belgium & $\begin{array}{l}2011 \text { (implemented } \\
\text { by } 2017-19): 33 \%\end{array}$ & $\begin{array}{l}\text { Soft: } \\
\text { - Void the appointment of any directors who do not } \\
\text { conform to board quota targets } \\
\text { - Appointments to any vacant positions are invalid as } \\
\text { long the quota is not fulfilled } \\
\text { - Suspension of any advantage, financial or } \\
\text { otherwise, for board members }\end{array}$ & $\begin{array}{l}\text { 2009: Corporate Governance Code recommends gender } \\
\text { diversity in board composition. }\end{array}$ \\
\hline \multicolumn{4}{|c|}{ - } \\
\hline \multicolumn{4}{|l|}{ Croatia } \\
\hline \multicolumn{4}{|l|}{ Cyprus } \\
\hline \multicolumn{4}{|c|}{ Czech Republic } \\
\hline Denmark & & & $\begin{array}{l}\text { 2013: Listed companies are obliged to self-regulate and } \\
\text { set their own targets, or can be fined. }\end{array}$ \\
\hline \multicolumn{4}{|r|}{ 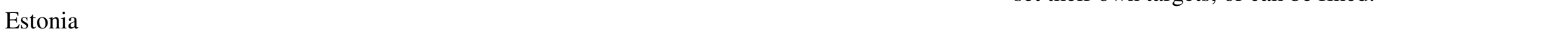 } \\
\hline Finland & & & $\begin{array}{l}\text { 2010: Corporate Governance Code for listed companies } \\
\text { recommends that boards include both women and men }\end{array}$ \\
\hline France & $\begin{array}{l}2011 \text { (implemented } \\
\text { by } 2017): 40 \%\end{array}$ & $\begin{array}{l}\text { Soft: } \\
\text { - Suspension of benefits of Directors } \\
\text { - Nullification of the board elections, but the } \\
\text { decisions adopted by the board remain valid }\end{array}$ & $\begin{array}{l}\text { 2011: AFEP-MEDEF Corporate Code has the same } \\
\text { recommendation as the quota law and is applicable to } \\
\text { all board members. }\end{array}$ \\
\hline Germany & $\begin{array}{l}2015 \text { (implemented } \\
\text { by } 2016): 30 \%\end{array}$ & $\begin{array}{l}\text { Soft: } \\
\text { - Leave position vacant } \\
\text { - "Empty chair sanction" }\end{array}$ & $\begin{array}{l}\text { 2010: Corporate Governance Code amended to } \\
\text { recommend an appropriate degree of women's } \\
\text { representation on supervisory boards }\end{array}$ \\
\hline \multicolumn{4}{|l|}{ Greece } \\
\hline \multicolumn{4}{|l|}{ Hungary } \\
\hline Iceland & $\begin{array}{l}2010 \text { (implemented } \\
\text { by } 2013 \text { ): } 40 \%\end{array}$ & $\begin{array}{l}\text { Hard } \\
\text { - Declaration of corrective measures } \\
\text { - Financial penalties }\end{array}$ & \\
\hline \multicolumn{4}{|c|}{ T) } \\
\hline Italy & $\begin{array}{l}2011 \text { (implemented } \\
\text { by } 2015): 33 \%\end{array}$ & $\begin{array}{l}\text { Hard } \\
\text { - } \quad \text { Fines } \\
\text { - } \quad \text { Directors lose office }\end{array}$ & \\
\hline
\end{tabular}


- Progressive sanctions: official warnings, fines, forfeiture of the offices of elected board members

Latvia

Lithuania

Luxembourg

Malta

Netherlands

2011 (initially Soft

implemented by - Statutory target

2016, extended to - "Comply or explain"

2010): $30 \%$

2006 (implemented Hard

by 2008$): 40 \%$

- Refuse to register board

- Dissolve company and delist from the stock exchange

- Official warnings

- Financial penalties until compliance

Poland

Portugal

Romania

Slovakia

Slovenia

Spain

2007 (implemented Soft

by 2015$): 40 \%$

contract

- No sanctions for failure to comply, but taking into account in procedures to award a public contract or the "equality label"

\section{Sweden}

United Kingdom

Source: based on European Commission (2012a); Cesifo (2013); Terjesen et al. (2015); European Commission (2016); Kirsch (2017); Kirsch (2018)
2009: Corporate Code recommends an appropriate representation of women and men among all board members.

2009: Corporate Governance Code recommends diversity for both executives and non-executives. Also, Voluntary Charter for more women in management.

2015: Government resolution encourages listed companies to attain $30 \%$ of the under-represented sex in their administrative bodies by 2018 .

2004: Corporate Governance Code has a voluntary goal of parity for listed companies.

2012: Corporate Governance Code (following the Lord

Davies' recommendation and subsequently HamptonAlexander review). 
Table 4: Correlation matrix

\begin{tabular}{|c|c|c|c|c|c|c|c|c|c|c|c|c|c|c|}
\hline & & 1 & 2 & 3 & 4 & 5 & 6 & 7 & 8 & 9 & 10 & 11 & 12 & 13 \\
\hline 1 & WoB 2006 & 1 & & & & & & & & & & & & \\
\hline 2 & WoB 2007 & 0.87 & 1 & & & & & & & & & & & \\
\hline 3 & WoB 2008 & 0.90 & 0.93 & 1 & & & & & & & & & & \\
\hline 4 & WoB 2009 & 0.85 & 0.91 & 0.96 & 1 & & & & & & & & & \\
\hline 5 & WoB 2010 & 0.82 & 0.91 & 0.91 & 0.95 & 1 & & & & & & & & \\
\hline 6 & WoB 2011 & 0.77 & 0.78 & 0.83 & 0.90 & 0.88 & 1 & & & & & & & \\
\hline 7 & WoB 2012 & 0.66 & 0.67 & 0.75 & 0.81 & 0.80 & 0.94 & 1 & & & & & & \\
\hline 8 & WoB 2013 & 0.51 & 0.56 & 0.63 & 0.72 & 0.70 & 0.84 & 0.94 & 1 & & & & & \\
\hline 9 & WoB 2014 & 0.45 & 0.46 & 0.53 & 0.63 & 0.63 & 0.78 & 0.89 & 0.95 & 1 & & & & \\
\hline 10 & WoB 2015 & 0.41 & 0.37 & 0.49 & 0.59 & 0.58 & 0.75 & 0.84 & 0.90 & 0.97 & 1 & & & \\
\hline 11 & WoB 2016 & 0.39 & 0.34 & 0.48 & 0.55 & 0.53 & 0.73 & 0.83 & 0.88 & 0.94 & 0.98 & 1 & & \\
\hline 12 & WoB 2017 & 0.35 & 0.33 & 0.47 & 0.55 & 0.53 & 0.73 & 0.81 & 0.86 & 0.92 & 0.97 & 0.99 & 1 & \\
\hline 13 & WoB 2018 & 0.30 & 0.29 & 0.44 & 0.52 & 0.50 & 0.70 & 0.80 & 0.87 & 0.92 & 0.96 & 0.98 & 0.99 & 1 \\
\hline 14 & Quotas 2006 & 0.63 & 0.57 & 0.71 & 0.68 & 0.60 & 0.61 & 0.56 & 0.43 & 0.36 & 0.34 & 0.36 & 0.34 & 0.30 \\
\hline 15 & Quotas 2007 & 0.31 & 0.30 & 0.44 & 0.44 & 0.38 & 0.38 & 0.34 & 0.27 & 0.23 & 0.21 & 0.24 & 0.23 & 0.21 \\
\hline 16 & Quotas 2008 & 0.31 & 0.30 & 0.44 & 0.44 & 0.38 & 0.38 & 0.34 & 0.27 & 0.23 & 0.21 & 0.24 & 0.23 & 0.21 \\
\hline 17 & Quotas 2009 & 0.31 & 0.30 & 0.44 & 0.44 & 0.38 & 0.38 & 0.34 & 0.27 & 0.23 & 0.21 & 0.24 & 0.23 & 0.21 \\
\hline 18 & Quotas 2010 & 0.18 & 0.22 & 0.34 & 0.42 & 0.35 & 0.41 & 0.52 & 0.55 & 0.48 & 0.45 & 0.44 & 0.41 & 0.40 \\
\hline 19 & Quotas 2011 & -0.08 & -0.02 & 0.09 & 0.16 & 0.13 & 0.29 & 0.41 & 0.50 & 0.55 & 0.58 & 0.63 & 0.64 & 0.62 \\
\hline 20 & Quotas 2012 & -0.08 & -0.02 & 0.09 & 0.16 & 0.13 & 0.29 & 0.41 & 0.50 & 0.55 & 0.58 & 0.63 & 0.64 & 0.62 \\
\hline 21 & Quotas 2013 & -0.08 & -0.02 & 0.09 & 0.16 & 0.13 & 0.29 & 0.41 & 0.50 & 0.55 & 0.58 & 0.63 & 0.64 & 0.62 \\
\hline 22 & Quotas 2014 & -0.08 & -0.02 & 0.09 & 0.16 & 0.13 & 0.29 & 0.41 & 0.50 & 0.55 & 0.58 & 0.63 & 0.64 & 0.62 \\
\hline 23 & Quotas 2015 & -0.08 & -0.03 & 0.09 & 0.16 & 0.12 & 0.29 & 0.41 & 0.49 & 0.57 & 0.59 & 0.65 & 0.67 & 0.66 \\
\hline 24 & Quotas 2016 & -0.08 & -0.03 & 0.09 & 0.16 & 0.12 & 0.29 & 0.41 & 0.49 & 0.57 & 0.59 & 0.65 & 0.67 & 0.66 \\
\hline 25 & Quotas 2017 & -0.08 & -0.03 & 0.09 & 0.16 & 0.12 & 0.29 & 0.41 & 0.49 & 0.57 & 0.59 & 0.65 & 0.67 & 0.66 \\
\hline 26 & Quotas 2018 & -0.08 & -0.03 & 0.09 & 0.16 & 0.12 & 0.29 & 0.41 & 0.49 & 0.57 & 0.59 & 0.65 & 0.67 & 0.66 \\
\hline 27 & GGI 2006 & 0.55 & 0.54 & 0.64 & 0.74 & 0.69 & 0.70 & 0.72 & 0.67 & 0.64 & 0.64 & 0.62 & 0.61 & 0.58 \\
\hline 28 & GGI 2007 & 0.56 & 0.54 & 0.63 & 0.74 & 0.69 & 0.73 & 0.74 & 0.70 & 0.68 & 0.67 & 0.65 & 0.64 & 0.61 \\
\hline 29 & GGI 2008 & 0.58 & 0.52 & 0.64 & 0.75 & 0.70 & 0.79 & 0.83 & 0.79 & 0.77 & 0.77 & 0.77 & 0.75 & 0.73 \\
\hline 30 & GGI 2009 & 0.53 & 0.49 & 0.61 & 0.72 & 0.67 & 0.76 & 0.83 & 0.81 & 0.79 & 0.78 & 0.78 & 0.76 & 0.74 \\
\hline 31 & GGI 2010 & 0.43 & 0.40 & 0.53 & 0.64 & 0.59 & 0.68 & 0.77 & 0.76 & 0.73 & 0.72 & 0.72 & 0.70 & 0.68 \\
\hline 32 & GGI 2011 & 0.41 & 0.39 & 0.51 & 0.63 & 0.58 & 0.68 & 0.76 & 0.75 & 0.73 & 0.72 & 0.72 & 0.70 & 0.69 \\
\hline 33 & GGI 2012 & 0.42 & 0.39 & 0.51 & 0.63 & 0.59 & 0.68 & 0.77 & 0.76 & 0.74 & 0.72 & 0.72 & 0.69 & 0.68 \\
\hline 34 & GGI 2013 & 0.42 & 0.39 & 0.51 & 0.62 & 0.59 & 0.69 & 0.79 & 0.78 & 0.77 & 0.75 & 0.74 & 0.71 & 0.70 \\
\hline 35 & GGI 2014 & 0.44 & 0.38 & 0.50 & 0.62 & 0.57 & 0.71 & 0.80 & 0.81 & 0.81 & 0.80 & 0.81 & 0.79 & 0.77 \\
\hline 36 & GGI 2015 & 0.44 & 0.34 & 0.48 & 0.56 & 0.50 & 0.66 & 0.78 & 0.78 & 0.77 & 0.77 & 0.79 & 0.75 & 0.74 \\
\hline 37 & GGI 2016 & 0.47 & 0.36 & 0.49 & 0.56 & 0.50 & 0.67 & 0.78 & 0.78 & 0.76 & 0.75 & 0.78 & 0.73 & 0.72 \\
\hline 38 & GGI 2017 & 0.50 & 0.41 & 0.51 & 0.58 & 0.51 & 0.69 & 0.78 & 0.80 & 0.77 & 0.76 & 0.77 & 0.73 & 0.72 \\
\hline 39 & GGI 2018 & 0.52 & 0.43 & 0.54 & 0.61 & 0.55 & 0.72 & 0.80 & 0.80 & 0.78 & 0.77 & 0.79 & 0.75 & 0.74 \\
\hline
\end{tabular}


Table 4: Correlation matrix (continued)

\begin{tabular}{|c|c|c|c|c|c|c|c|c|c|c|c|c|c|}
\hline & 14 & 15 & 16 & 17 & 18 & 19 & 20 & 21 & 22 & 23 & 24 & 25 & 26 \\
\hline WoB 2006 & & & & & & & & & & & & & \\
\hline WoB 2007 & & & & & & & & & & & & & \\
\hline WoB 2008 & & & & & & & & & & & & & \\
\hline WoB 2009 & & & & & & & & & & & & & \\
\hline WoB 2010 & & & & & & & & & & & & & \\
\hline WoB 2011 & & & & & & & & & & & & & \\
\hline WoB 2012 & & & & & & & & & & & & & \\
\hline WoB 2013 & & & & & & & & & & & & & \\
\hline WoB 2014 & & & & & & & & & & & & & \\
\hline WoB 2015 & & & & & & & & & & & & & \\
\hline WoB 2016 & & & & & & & & & & & & & \\
\hline WoB 2017 & & & & & & & & & & & & & \\
\hline WoB 2018 & & & & & & & & & & & & & \\
\hline Quotas 2006 & 1 & & & & & & & & & & & & \\
\hline Quotas 2007 & 0.69 & 1 & & & & & & & & & & & \\
\hline Quotas 2008 & 0.69 & 1.00 & 1 & & & & & & & & & & \\
\hline Quotas 2009 & 0.69 & 1.00 & 1.00 & 1 & & & & & & & & & \\
\hline Quotas 2010 & 0.56 & 0.80 & 0.80 & 0.80 & 1 & & & & & & & & \\
\hline Quotas 2011 & 0.34 & 0.48 & 0.48 & 0.48 & 0.60 & 1 & & & & & & & \\
\hline Quotas 2012 & 0.34 & 0.48 & 0.48 & 0.48 & 0.60 & 1.00 & 1 & & & & & & \\
\hline Quotas 2013 & 0.34 & 0.48 & 0.48 & 0.48 & 0.60 & 1.00 & 1.00 & 1 & & & & & \\
\hline Quotas 2014 & 0.34 & 0.48 & 0.48 & 0.48 & 0.60 & 1.00 & 1.00 & 1.00 & 1 & & & & \\
\hline Quotas 2015 & 0.31 & 0.44 & 0.44 & 0.44 & 0.55 & 0.91 & 0.91 & 0.91 & 0.91 & 1 & & & \\
\hline Quotas 2016 & 0.31 & 0.44 & 0.44 & 0.44 & 0.55 & 0.91 & 0.91 & 0.91 & 0.91 & 1.00 & 1 & & \\
\hline Quotas 2017 & 0.31 & 0.44 & 0.44 & 0.44 & 0.55 & 0.91 & 0.91 & 0.91 & 0.91 & 1.00 & 1.00 & 1 & \\
\hline Quotas 2018 & 0.31 & 0.44 & 0.44 & 0.44 & 0.55 & 0.91 & 0.91 & 0.91 & 0.91 & 1.00 & 1.00 & 1.00 & 1 \\
\hline GGI 2006 & 0.37 & 0.34 & 0.34 & 0.34 & 0.46 & 0.17 & 0.17 & 0.17 & 0.17 & 0.23 & 0.23 & 0.23 & 0.23 \\
\hline GGI 2007 & 0.37 & 0.35 & 0.35 & 0.35 & 0.46 & 0.20 & 0.20 & 0.20 & 0.20 & 0.27 & 0.27 & 0.27 & 0.27 \\
\hline GGI 2008 & 0.43 & 0.33 & 0.33 & 0.33 & 0.47 & 0.31 & 0.31 & 0.31 & 0.31 & 0.33 & 0.33 & 0.33 & 0.33 \\
\hline GGI 2009 & 0.39 & 0.31 & 0.31 & 0.31 & 0.50 & 0.33 & 0.33 & 0.33 & 0.33 & 0.35 & 0.35 & 0.35 & 0.35 \\
\hline GGI 2010 & 0.41 & 0.37 & 0.37 & 0.37 & 0.58 & 0.35 & 0.35 & 0.35 & 0.35 & 0.37 & 0.37 & 0.37 & 0.37 \\
\hline GGI 2011 & 0.39 & 0.36 & 0.36 & 0.36 & 0.56 & 0.34 & 0.34 & 0.34 & 0.34 & 0.37 & 0.37 & 0.37 & 0.37 \\
\hline GGI 2012 & 0.37 & 0.25 & 0.25 & 0.25 & 0.47 & 0.30 & 0.30 & 0.30 & 0.30 & 0.32 & 0.32 & 0.32 & 0.32 \\
\hline GGI 2013 & 0.37 & 0.25 & 0.25 & 0.25 & 0.49 & 0.33 & 0.33 & 0.33 & 0.33 & 0.34 & 0.34 & 0.34 & 0.34 \\
\hline GGI 2014 & 0.34 & 0.22 & 0.22 & 0.22 & 0.43 & 0.37 & 0.37 & 0.37 & 0.37 & 0.41 & 0.41 & 0.41 & 0.41 \\
\hline GGI 2015 & 0.35 & 0.24 & 0.24 & 0.24 & 0.47 & 0.38 & 0.38 & 0.38 & 0.38 & 0.41 & 0.41 & 0.41 & 0.41 \\
\hline GGI 2016 & 0.35 & 0.24 & 0.24 & 0.24 & 0.48 & 0.35 & 0.35 & 0.35 & 0.35 & 0.37 & 0.37 & 0.37 & 0.37 \\
\hline GGI 2017 & 0.31 & 0.23 & 0.23 & 0.23 & 0.48 & 0.29 & 0.29 & 0.29 & 0.29 & 0.32 & 0.32 & 0.32 & 0.32 \\
\hline GGI 2018 & 0.35 & 0.25 & 0.25 & 0.25 & 0.47 & 0.31 & 0.31 & 0.31 & 0.31 & 0.34 & 0.34 & 0.34 & 0.34 \\
\hline
\end{tabular}


Table 4: Correlation matrix (continued)

\begin{tabular}{|c|c|c|c|c|c|c|c|c|c|c|c|c|c|c|}
\hline & & 27 & 28 & 29 & 30 & 31 & 32 & 33 & 34 & 35 & 36 & 37 & 38 & 39 \\
\hline 1 & WoB 2006 & & & & & & & & & & & & & \\
\hline 2 & WoB 2007 & & & & & & & & & & & & & \\
\hline 3 & WoB 2008 & & & & & & & & & & & & & \\
\hline 4 & WoB 2009 & & & & & & & & & & & & & \\
\hline 5 & WoB 2010 & & & & & & & & & & & & & \\
\hline 6 & WoB 2011 & & & & & & & & & & & & & \\
\hline 7 & WoB 2012 & & & & & & & & & & & & & \\
\hline 8 & WoB 2013 & & & & & & & & & & & & & \\
\hline 9 & WoB 2014 & & & & & & & & & & & & & \\
\hline 10 & WoB 2015 & & & & & & & & & & & & & \\
\hline 11 & WoB 2016 & & & & & & & & & & & & & \\
\hline 12 & WoB 2017 & & & & & & & & & & & & & \\
\hline 13 & WoB 2018 & & & & & & & & & & & & & \\
\hline 14 & Quotas 2006 & & & & & & & & & & & & & \\
\hline 15 & Quotas 2007 & & & & & & & & & & & & & \\
\hline 16 & Quotas 2008 & & & & & & & & & & & & & \\
\hline 17 & Quotas 2009 & & & & & & & & & & & & & \\
\hline 18 & Quotas 2010 & & & & & & & & & & & & & \\
\hline 19 & Quotas 2011 & & & & & & & & & & & & & \\
\hline 20 & Quotas 2012 & & & & & & & & & & & & & \\
\hline 21 & Quotas 2013 & & & & & & & & & & & & & \\
\hline 22 & Quotas 2014 & & & & & & & & & & & & & \\
\hline 23 & Quotas 2015 & & & & & & & & & & & & & \\
\hline 24 & Quotas 2016 & & & & & & & & & & & & & \\
\hline 25 & Quotas 2017 & & & & & & & & & & & & & \\
\hline 26 & Quotas 2018 & & & & & & & & & & & & & \\
\hline 27 & GGI 2006 & 1 & & & & & & & & & & & & \\
\hline 28 & GGI 2007 & 0.99 & 1 & & & & & & & & & & & \\
\hline 29 & GGI 2008 & 0.93 & 0.95 & 1 & & & & & & & & & & \\
\hline 30 & GGI 2009 & 0.93 & 0.94 & 0.99 & 1 & & & & & & & & & \\
\hline 31 & GGI 2010 & 0.92 & 0.93 & 0.94 & 0.96 & 1 & & & & & & & & \\
\hline 32 & GGI 2011 & 0.93 & 0.93 & 0.94 & 0.96 & 1.00 & 1 & & & & & & & \\
\hline 33 & GGI 2012 & 0.91 & 0.92 & 0.93 & 0.95 & 0.98 & 0.98 & 1 & & & & & & \\
\hline 34 & GGI 2013 & 0.89 & 0.90 & 0.93 & 0.95 & 0.97 & 0.98 & 1.00 & 1 & & & & & \\
\hline 35 & GGI 2014 & 0.85 & 0.88 & 0.93 & 0.94 & 0.95 & 0.95 & 0.96 & 0.96 & 1 & & & & \\
\hline 36 & GGI 2015 & 0.83 & 0.85 & 0.91 & 0.93 & 0.93 & 0.93 & 0.93 & 0.93 & 0.95 & 1 & & & \\
\hline 37 & GGI 2016 & 0.81 & 0.83 & 0.90 & 0.92 & 0.92 & 0.92 & 0.91 & 0.92 & 0.93 & 0.99 & 1 & & \\
\hline 38 & GGI 2017 & 0.80 & 0.82 & 0.88 & 0.90 & 0.88 & 0.88 & 0.86 & 0.87 & 0.92 & 0.95 & 0.96 & 1 & \\
\hline 39 & GGI 2018 & 0.83 & 0.86 & 0.91 & 0.93 & 0.90 & 0.90 & 0.88 & 0.89 & 0.93 & 0.96 & 0.97 & 0.99 & 1 \\
\hline
\end{tabular}


Table 5: Panel regression results (dependent variable: Women's representation on boards)

\begin{tabular}{|c|c|c|c|c|c|c|c|c|c|c|c|c|}
\hline & \multicolumn{3}{|c|}{ Model 1} & \multicolumn{3}{|c|}{ Model 2} & \multicolumn{3}{|c|}{ Model 3} & \multicolumn{3}{|c|}{ Model 4} \\
\hline & $\beta$ & $\mathrm{SE}$ & Sig. & $\beta$ & $\mathrm{SE}$ & Sig. & $\beta$ & SE & Sig. & $\beta$ & $\mathrm{SE}$ & Sig. \\
\hline Constant & 16.92 & 1.46 & $* *$ & 9.65 & 1.72 & $* *$ & 16.72 & 1.32 & $* *$ & 16.52 & 1.31 & $* *$ \\
\hline Gender equality & 1.40 & 0.07 & $* *$ & & & & 1.22 & 0.07 & $* *$ & 1.13 & 0.08 & $* *$ \\
\hline Legislated quotas & & & & 11.99 & 1.13 & $* *$ & 7.61 & 0.87 & $* *$ & 6.63 & 0.96 & $* *$ \\
\hline $\begin{array}{l}\text { Legislated quotas } \\
\text { x Gender equality }\end{array}$ & & & & & & & & & & 0.35 & 0.15 & * \\
\hline $\begin{array}{l}\text { Control for GDP } \\
\text { per capita }\end{array}$ & Yes & & & Yes & & & Yes & & & Yes & & \\
\hline $\begin{array}{l}\text { Controls for years } \\
\text { 2007-18 } \\
\end{array}$ & Yes & & & Yes & & & Yes & & & Yes & & \\
\hline $\mathbf{R}^{2}$ & 0.607 & & & 0.396 & & & 0.679 & & & 0.684 & & \\
\hline $\mathbf{F}$ & 41.126 & & $* *$ & 17.461 & & $* *$ & 52.140 & & $* *$ & 49.649 & & $* *$ \\
\hline
\end{tabular}


Figure 1 Interaction effect of the presence of quotas and gender equality on women's board representation

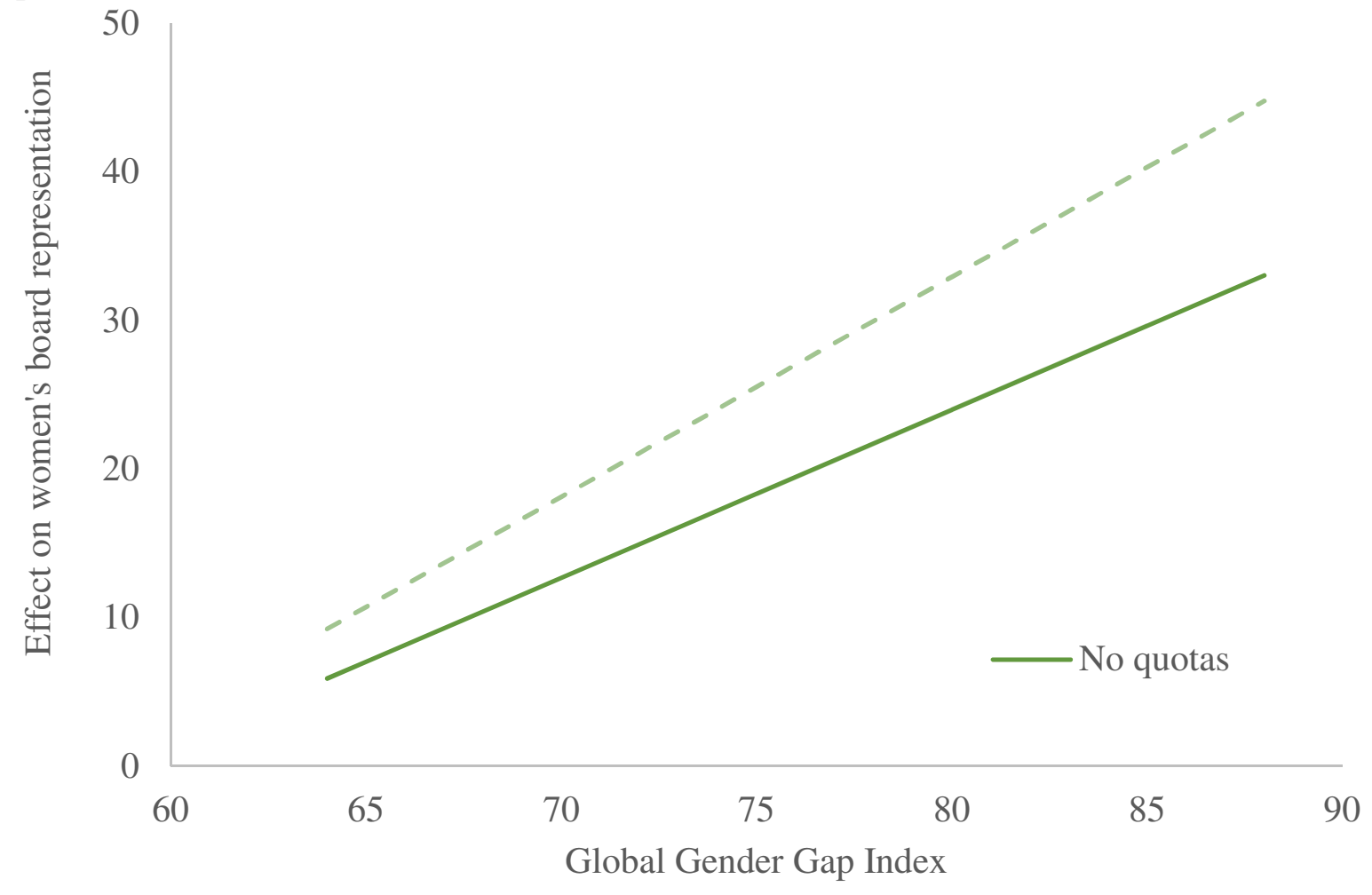


Table 6: Panel regression results - post-hoc analysis (dependent variable: Women's representation on boards)

\begin{tabular}{|c|c|c|c|c|c|c|c|c|c|c|c|c|c|c|c|}
\hline & \multicolumn{3}{|c|}{ Model 5} & \multicolumn{3}{|c|}{ Model 6} & \multicolumn{3}{|c|}{ Model 7} & \multicolumn{3}{|c|}{ Model 8} & \multicolumn{3}{|c|}{ Model 9} \\
\hline & $\beta$ & SE & Sig. & $\beta$ & SE & Sig. & $\beta$ & SE & Sig. & $\beta$ & SE & Sig. & $\beta$ & SE & Sig. \\
\hline Constant & 10.24 & 1.63 & $* *$ & 13.50 & 1.58 & $* *$ & 17.63 & 1.28 & $* *$ & 16.37 & 1.34 & $* *$ & 16.40 & 1.34 & $* *$ \\
\hline Gender equality & & & & & & & 1.05 & 0.07 & $* *$ & 0.82 & 0.10 & $* *$ & 0.84 & 0.10 & $* *$ \\
\hline Quota with hard sanction & 18.94 & 1.55 & $* *$ & 23.03 & 1.54 & $* *$ & 14.14 & 1.36 & $* *$ & 12.82 & 1.58 & $* *$ & 12.78 & 1.58 & $* *$ \\
\hline Quota with soft sanction & 7.20 & 1.32 & $* *$ & 10.36 & 1.30 & $* *$ & 6.98 & 1.05 & $* *$ & 7.02 & 1.23 & $* *$ & 7.56 & 1.06 & *** \\
\hline Code of governance & & & & 8.97 & 1.20 & $* *$ & 4.27 & 1.00 & $* *$ & 3.32 & 1.16 & $* *$ & 3.26 & 1.15 & ** \\
\hline $\begin{array}{l}\text { Legislated quotas with hard sanction } x \text { Gender } \\
\text { equality }\end{array}$ & & & & & & & & & & 0.43 & 0.18 & $*$ & 0.41 & 0.18 & * \\
\hline Legislated quotas with soft sanction $x$ Gender equality & & & & & & & & & & 0.37 & 0.44 & & & & \\
\hline Code of governance $x$ Gender equality & & & & & & & & & & 0.54 & 0.20 & $* *$ & 0.53 & 0.20 & $* *$ \\
\hline Control for GDP per capita & Yes & & & Yes & & & Yes & & & Yes & & & Yes & & \\
\hline Controls for years 2007-18 & Yes & & & Yes & & & Yes & & & Yes & & & Yes & & \\
\hline $\mathbf{R}^{2}$ & .458 & & & .533 & & & .711 & & & .720 & & & .719 & & \\
\hline $\mathbf{F}$ & 20.792 & $* *$ & & 26.186 & $* *$ & & 52.694 & $* *$ & & 45.962 & $* *$ & & 48.513 & $* *$ & \\
\hline
\end{tabular}

$\mathrm{p}<.05$

$* * \mathrm{p} \leq .01$ 
Figure 2 Interaction effects of the types of measures and gender equality on women's board representation

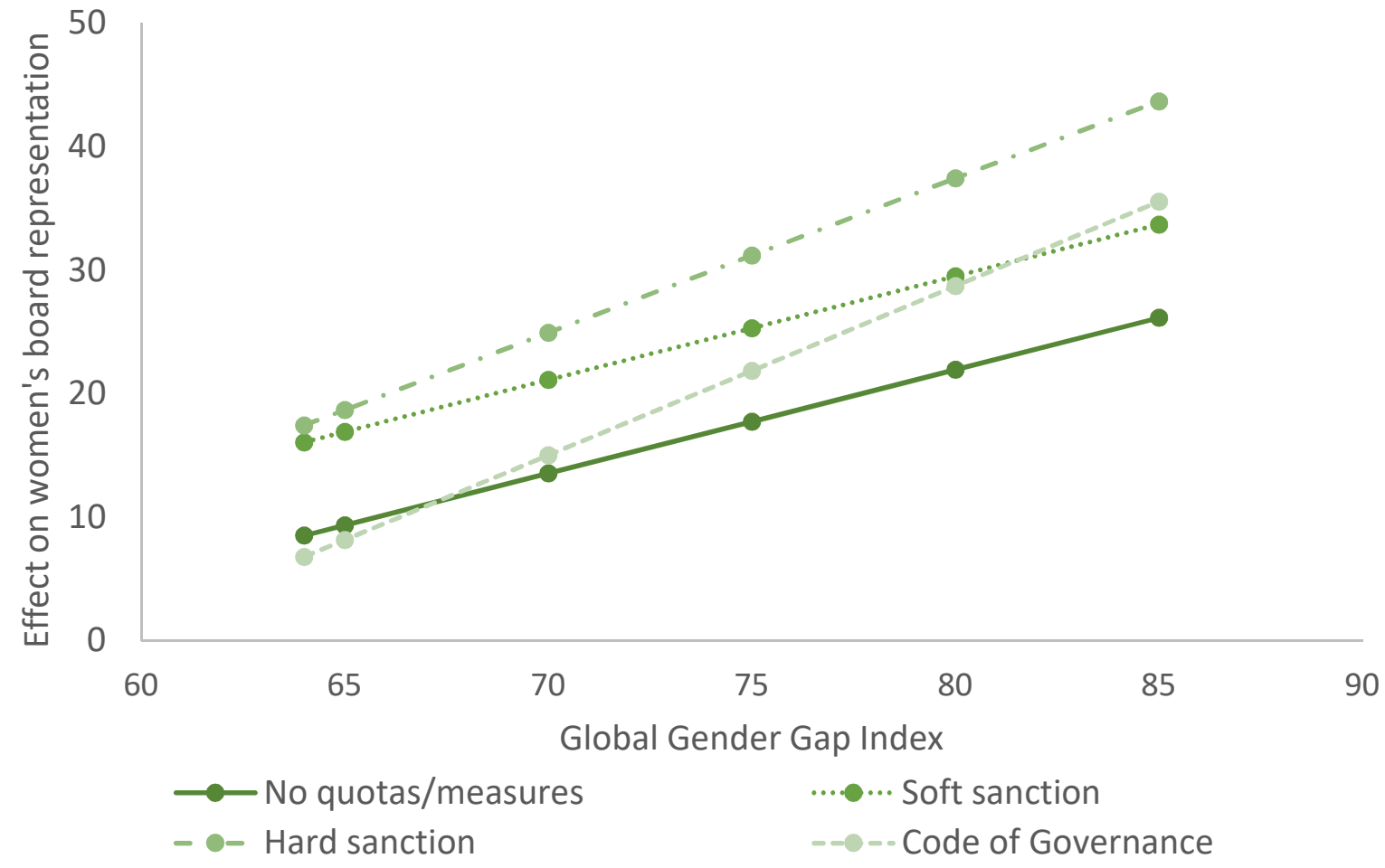

